\title{
Sarmackie widzenie świata. O stylu poezji Wespazjana Kochowskiego
}

Artur Rejter 


\section{Artur Rejter}

\section{Sarmackie widzenie świata. O stylu poezji Wespazjana Kochowskiego}

$\mathrm{W}$

ielogłosowość, niejednoznaczność i eklektyzm baroku jako epoki w dziejach nowożytnych stanowią o jego atrakcyjności zarówno dla współczesnych odbiorców tekstów kultury tego okresu, jak też dla badaczy. Sarmatyzm — jeden z nurtów baroku — jest formacją kulturową, która bezsprzecznie wpływała na świadomość Polaków nie tylko w okresie największego rozkwitu i popularności sarmackiej ideologii i obyczajowości. Założenia i wpływy sarmatyzmu stały się przedmiotem refleksji dla twórców i uczonych, począwszy od baroku, a skończywszy na czasach współczesnych ${ }^{1}$. Ocena sarmatyzmu wahała się od skrajnych ujęć krytycznych poprzez bezrefleksyjną apologię aż do obiektywnych ocen naukowców, które w dużej mierze determinują kierunek badań nowoczesnej humanistyki ${ }^{2}$. I choć niektórzy badacze starają się uwypuklić inne, niesarmackie aspekty polskiego baroku ${ }^{3}$, to jednak nie można zaprzeczyć niepośledniej roli niezwykłej formacji kulturowej, ukształtowanej w drugiej połowie XVI stulecia. Oczywiście, pozostaje barok eteryczny, metafizyczny, „wyzwolony”, z całym spektrum zaniedbanych problemów i zapomnianych twórców, niemniej to właśnie kultura sarmacka do dziś kojarzy się z Polską swojską, Polską jako pewną osobliwością na mapie ówczesnej Europy.

Sarmatyzm stworzył swoją literaturę, której przedstawiciele najczęściej dowodzili swoim życiem i postawą silnych związków z tą formacją ideologiczno-kulturową. Tak też jest w wypadku Wespazjana Kochowskiego ${ }^{4}$. Ten wszechstronny poeta, swobodnie przechodzący w swojej twór-

1 Zob. M. Głowiński, T. Kostkiewiczowa, A. Okopicń-Sławińska, J. Sławiński, Słownik terminów literackich, Wrocław 1989 , s. 455-456.

2 Zob. np.: M. Klimowicz, Oświecenie, Warszawa 1998, s. 11-17; J. Pclc, Barok - epoka przeciureństw, Warszawa 1993, s. 207-269; idem, Sarmatyzm, w: Slounik literatury staropolskiej. Średniowiecze - Renesans - Barok, red. T. Michałowska, Wrocław 1998, s. 834-838.

${ }^{3}$ Zob. A. Czyż, Polski barok niesarmacki, w: idem, Wadza marzeń. Studia o wyobraźni i tekstach, Bydgoszcz 1997 , s. 161-173, a takż inne artykuły z tego tomu.

${ }^{4}$ Zob. np. M. Eustachicwicz, Wstęp, w: W. Kochowski, Utwory poetyckie. Wybór, opr. M. Eustachicwicz, Wrocław 1991 
czości od problematyki obyczajowej przez publicystyczną aż do religijnej, pozostawił świadectwo silnej determinacji własnymi zasadami i priorytetami życiowymi.

Niniejszy artykuł jest próbą lingwostylistycznego spojrzenia na twórczość Kochowskiego przez pryzmat wzorca Sarmaty - patrioty, szlachcica, człowieka walczącego o dobro własnego stanu i ojczyzny, walecznego i odważnego żołnierza. Dlatego też skupiono się na wybranych tekstach ze zbioru Niepróżnujace próżnowanie. Obserwacją objęto księgi: I, IV i V (Epodon) cyklu Lyricorum polskich, zawierające utwory tematycznie skoncentrowane wokół zagadnień bohaterstwa, waleczności, patriotyzmu i wojny. Właśnie na te teksty szczególny wpływ miały Klio, Bellona, Kamena...

W jakże różnorodnej pod względem treści i formy poezji Kochowskiego jednym z kreowanych światów jest właśnie Sarmacja z jej „głównym bohaterem” - polskim Sarmatą. Twórca prowadzi czytelnika po rzeczywistości zbudowanej z niezliczonych obrazów składających się na wizerunek tak bliskiej mu krainy. Pozwala to odtworzyć stereotyp Sarmaty, czyli:

...subiektywnie determinowane wyobrażenie przedmiotu obejmujące zarówno jego cechy opisowe, jak i wartościujące obraz, oraz będące rezultatem interpretacji rzeczywistości w ramach społecznych modeli poznawczych ${ }^{5}$,

w tym wypadku dotyczących Sarmaty właśnie. W niniejszym artykule właściwie mowa będzie o autostereotypie, ponieważ wizerunek Sarmaty tworzony jest przez przedstawiciela tej grupy są to tak zwane wyobrażenia o sobie ${ }^{6}$. Stereotypy jako elementy językowego obrazu świata stanowią więc interpretację rzeczywistości nawet odległej w czasie, na przykład barokowej.

Jak na barok przystało, kreacja świata w poezji Kochowskiego jest niezwykle bogata i dynamiczna pod względem stylu. W jednym tekście spotkać można zarówno konstrukcje kolokwialne, rubaszne, jak i wyszukane, kunsztowne tropy przynależne do stylu wysokiego (retorycznego). Jest to cecha całego cyklu Niepróżnujące próżnowanie ${ }^{7}$.

Obrazy tworzone przez Kochowskiego oparte są przede wszystkim na kontraście - to on właśnie stanowi dominantę stylistyczną poezji poddanej obserwacji. Kontrast jest przecież uważany za konstytutywną cechę stylistyczną poezji barokowej ${ }^{8}$.

Tak po twej śmierci ciężkich wojen cienie

Niesłychane nam sprawiły zaćmienie.

Już upadła Lecha

Ostatnia pociecha,

A tym mizerniej, gdy Polskę wojują

Źli buntownicy z wyuzdanym szują.

(BN I 92), s. III-LXXX (wszystkie przytoczenia za tą edycja); C. Hernas, Barok, Warszawa 1998, s. 481-509.

${ }^{5} \mathrm{~J}$. Bartmiński, Podstawy lingwistycznych badań nad stereotypem - na przykladzie stereotypu matki, w: Jezүk a kultura, t. 12, Stereotyp jako przedmiot linguistyki. Teoria, metodologia, analizy empiryczne, red. J. Anusiewicz, J. Bartmiński, Wrocław 1998, s. 64.

${ }^{6}$ W odróżnieniu od heterostereotypu, czyli wyobrażeń o innych. Szerzcj na ten temat zob. J. Bartmiński, Punkt widzenia, perspektywa, jęzłkowy obraz świata, w: Jezykowy obraz świata, red. J. Bartmiński, Lublin 1999, s. 103-120.

7 Zob. M. Eustachiewicz, op. cit., s. XXX-XXXI.

8 Zob. T. Skubalanka, Historyczna stylistyka języka polskiego. Przekroje, Wrocław 1984, s. 83. 
Raz bywa znośniejszy

$Z$ ręki potężniejszéj;

Leć ten nierównie nad człekiem się sroży,

Gdy chłop do karku panu miecz przyłoży.

Takli orzeł biały,

Król ptaków wspaniały,

Wczora swe skrzydła nad narody szerzy,

Dziś śmiercią króla marnie się wypierzy.

Depce Turkom szyje,

Ordę, Szwedy bije,

Uporną Moskwę tak pazury ściśnie,

W których ujęty obłów ani piśnie,

$\mathrm{A} \dot{z}$ onej orlice

Przezorne źrenice

Nieprosto w słońce patrzącej się chwieją,

$\mathrm{Z}$ czego narody postronne się śmieja.

(Żatoba albo wiersz o śmierci niezwyciężonego Wtadystawa IV, L I 1, w. 19-40, s. 9-10)

Niewyszukana leksyka i frazeologia (szuja, ani piśnie) sąsiaduje tutaj z kunsztowną metaforą-symbolem orła. Ptak jako synonim potęgi i chwały Polski niszczy opisanych wrogów w sposób dosadny i bezpośredni. Patos naddany symbolowi jako jednemu z tropów zderzony zostaje w powyższej pieśni z potocznością deskrypcji. Powaga tematu, jego ważkość jest zatem odciążona poprzez swojskość (styl potoczny) charakterystyk. Swojskość owa to właśnie jedna z prototypowych cech kreacji rzeczywistości sarmackiej.

Niejednokrotnie w poezji Kochowskiego sąsiadują ze sobą całe konteksty komunikatu utrzymane w zupełnie różnych, często przeciwstawnych, konwencjach stylistycznych:

[1] ...Pogląda w różne klimata i strony, Szpera pod słońcem, czy się znajdzie który,

Na czyjej ręce mógłby poróść pióry?

Puści wzrok bystry, wzrok niedościgniony,

$\mathrm{Na}$ wiecznym mrozem zjęte Akwilony,

Ale swobody ptak pamiętny swojéj,

Ciężkich się pędzców i niewoli boi.

Ani on na tej opaść ręce zechce,

Kędy go wabi i kędy go łechce

Szwistny wab chytrych i słodkie namowy -

On na lilijach paść się niegotowy.

Wabi go i ten, co kiedyś zbawiony

Był spokrewnieniem tej zacnej Korony,

Leć nie chce jakoś w knieję tę głęboką,

Gdzie cudzych kurcząt musiałby być kwoką. (...) 
[2] Darmo to, ludzie, koncepty wywierać,

Bóg nie da w swoich ordynansach szperać.

Bóg króle daje, potentaty zruca,

Cichych podnosi, a hardych zasmuca,

Przetoż i ty, mój bracie Polaninie,

Tu w zagęszczonym zgromadzony gminie,

Ku Bogu oczy swe obróć do nieba,

On ci da pana, jakiego-ć potrzeba.

Nie sobie króla, leć wszytkim obieraj,

$\mathrm{Z}$ cnoty, nie $\mathrm{z}$ datku, godnego popieraj,

Nie za kim szwedzkie i Bonzego chęci,

Leć kogo-ć dzielność przymiotów zaleci.

Niech cię ustraszą przeszłe interregna,

Mokre krwią polską pokazując ściegna.

Pódźcie, synowie jednej matki, zgodą -

Prywaty na bok niechaj was nie wioda.

(Zgoda do braciej..., L IV 18, w. 38-52, 69-84, s. 157-159)

Niezwykle plastyczny i sugestywny obraz orla jako symbolu Polski [1] jest niejako wprowadzeniem w jakże odmienny stylistycznie segment tekstu [2]. Zdecydowanie istotniejszy wydaje się bezpośredni apel, odezwa do Polaków, odwolanie się do ich zdrowego rozsądku [2]. Wyznacznikiem kontrastu w płaszczyźnie języka jest zderzenie elementów różnych konwencji poetyckich. Pierwszą z nich współtworzy nagromadzenie leksyki wyszukanej (literackiej): mrozem zjęte Akwilony, tropów: wzrok bystry, wzrok niedościgniony, drugą zaś słownictwo neutralne, pozbawione artystycznych konotacji (bliskie potocznej odmianie języka). Na poziomie składni zwraca uwagę tendencja do konstrukcji starannych, urozmaiconych w segmencie pierwszym, na przykład strofa zaczynająca się od słów: „Ani on na tej opaść ręce zechce...", oraz prostota i nagromadzenie zdań imperatywnych w drugim, na przykład: „Pódźcie, synowie jednej matki, zgodą — / Prywaty na bok niechaj was nie wiodą”.

Sarmata to bohater bliski poecie, Polak waleczny i odważny, dla którego wzorami i punktem odniesienia bywają postaci ze świata historii starożytnej i mitologii:

Tam, gdzie kozacką wspienione posoką

Wody się Styru blotnistego wloka,

A buntowniczym trupom w lgniącym bagnie

Grób się stał na dnie,

Ku wschodowi się obracając w lewo,

Piękny pagórek cyprysowe drzewo

Gęste osiadło. Tam gdy Febus skłoni,

Tak w cytrę dzwoni: (...)

Sam pod buńczuki Tatarzy majaczą,

Zielone chana ich chorągwie znaczą, 
A tego zwycięstw rozdyma nadzieja,

\section{Isłan Giereja.}

Poniżej polskie bielą się namioty,

Przed nimi stoją liczne w szyku roty,

Proporce $z$ wiatrem wolniuchnym igraja,

Konie tupają.

Cokolwiek obłał Euksyn starożytny

Narodów, aż po ocean błękitny,

Od gór Karpackich, aże do krainy

\section{Leśnej Hercyny, (...)}

Lecą chorąwie, jako kiedy śniegi

Ze dwóch gór czynią topniejąc zabiegi,

Skąd woda bystrsza, ta wypiera drugą

Mocniejszą strugą.

Potocki środkiem ważnym idzie krokiem,

Prawym przywodzi Kalinowski bokiem,

A za swych wodzów skutecznym przykładem

Młódź idzie śladem.

Sam z Koniecpolskim Zamojski podczaszy,

Dwaj Tyndaridae Sarmacyjej naszéj,

I Lanckoroński z młodym Ostrorogiem

Kozakom srogiem.

Pulk Ostrogskiego od nich okryt całkiem,

Tu z Lubomierskim Tyszkiewic marszałkiem,

Z nimi Sczawiński i Potocki stary

$$
\text { Pędzą Tatary. (...) }
$$

Już Ossoliński z Lanckorońskim legli

Mężowie biegli,

Już Kazanowski, człowiek z przodków wzięty,

W naczelnych pułkach bój wszczynając, ścięty.

Już i Stadnicki, najeźnik surowy,

Został bez głowy.

Ale nie darmo krew się leje droga,

W Kozakach klęska nagradza ją sroga;

Bierze sowite $z$ zabitych dusz dani

Erebu pani. (...)

W taborze Kozak myśli-ć o tej Hydrze,

Której-ć Mulcyber żaden już nie wydrze,

Polaku! Stolbej gadziny ostatki

Wpadły-ć do łapki.

Wtem, gdy do szturmu polska młódź iść miała,

Apollinowi strona się zerwała, 
Którą gdy wiąże, a tymczasem wściekli

Chłopi uciekli.

(Berestecka potrzebę Apollo śpiewa, L I 9, w. 1-8, 17-28, 41-56, 79-88, 93-100, s. 24-29)

Przywołana pieśń zbudowana została głównie na znacznym nagromadzeniu nazw własnych, które w połączeniu z dynamiką deskrypcji dają interesujący obraz Sarmacji jako świata ludzi mężnych i zdeterminowanych żądzą walki o dobro ojczyzny. Widać jednak, że ważniejsi od starożytnych są bohaterowie współcześni, co przejawia się w dokładniejszej ich charakterystyce. Nazwy osobowe odnoszące się do świata współczesnego poecie opatrzone są zazwyczaj epitetami lub innymi środkami służącymi ich dokładniejszemu opisowi. Natomiast elementy rzeczywistości antycznej najczęściej zostają jedynie przywołane bez żadnych atrybutów. Świat starożytny zatem jest dobrze rozpoznawalnym tłem dla wydarzeń i postaci świata Sarmacji.

Wzorców dla Polaka-Sarmaty szuka Kochowski także wśród poetów, twórców literatury i kultury:

Hetmanem w polskich tym poetów gronie

Jan Kochanowski bluszczem okrył skronie,

Po nim Piotr, temu daja jego rymy

Z odwetowanej dank Hierozolimy.

Miaskowskim chwalna wielgopolska knieja,

Oksyca obok postawiono Reja,

Z tymi Trzecieski wraz z Acernem stoi

I Jagodyński, Rusi chwała swojéj.

Jest i Petrycy, co u Moskiewskiego

$\mathrm{W}$ polski ton stroił lirę Horacego,

Także Żebrowski w tejż z nimi gromadzie,

Co go tłumaczem Przemian Nazo kładzie,

Dalej są inszy. Ale $z$ inszych wiela

Znaczniejszy widać obraz Samuela

Z Skrzypnej, nowego Sarmatów Marona,

Którego tak zwać każe Melpemona.

$Z$ tej galeryjej gabinet jest wedle

Tak przeźroczysty, jako we zwierciedle,

W którym rzemieśnik w tym kunszcie nieprosty

Odnawiał świeżej roboty pokosty.

Sadzi Morsztyna w senatorskim krześle

Z Skarszewskim, obu biegłych w tym rzemieśle;

Tamtego wdzięczna Psyche i Ksymena,

Tego Moskiewska zaleca Kamena.

Więc senatory tym żeby znać czynem,

Pod tymże z nimi stoją baldekinem 
I z Lubomirskim Lacki, sobie wszędzie

W wierszów pisaniu równi i w urzędzie.

(Poetowie polscyświeższy i dawniejszy we dworze helikońskimodmalowani, L Ep. 6, w. 29-56, s. 198-200)

I znów nazwiska Polaków pojawiają się w sąsiedztwie postaci z innych kręgów kulturowych (między innymi z antyku). Nieprzypadkowo wybór padł na twórców literatury - Kochowski chciał zapewne uwypuklić własny, analogiczny wkład w kulturę polską. Charakterystyczny dla powyższego utworu jest rozmach, z jakim poeta przywołuje liczne nazwiska, okraszając je krótką charakterystyką. Owo typowo barokowe bogactwo znajduje wyraz także na płaszczyźnie językowej — zwraca uwagę między innymi kunsztowna składnia (na przykład „Hetmanem w polskich tym poetów gronie / Jan Kochanowski bluszczem okrył skronie”), porównania („Z tej galeryjej gabinet jest wedle / Tak przeźroczysty, jako we zwierciedle”) czy liczne epitety. Formalna strona tekstu ma pewnie współgrać z jego tematyką, stąd jej artystyczne, retoryczne nacechowanie.

Sarmacka ideologia znajduje również wyraz w pieśniach w całości opartych na koncepcie:

Oj, nie rzecz, nie rzecz i nam mniej przystoi,

Mężnych Lechitów synom, bracia moi,

W obozie ze śkła, winem zlanym hojnie,

Mówić o wojnie.

Placem wojennym nam stół, arsenałem

Piwnica, gdzie dość municjej zastałem;

Bachus hetmanem, mistrz artyleryje,

Kto lepiej pije.

$\mathrm{Z}$ mis beloardy, z pasztetów reduty,

$Z$ kopy kuropatw szańc wielki usuty,

Marcypanowej palisada wieże

Cukrowa strzeże,

Koło której są po suggestach działa,

A jak na hasło armata zagrzmiała:

Pierwsza za zdrowie, pij, nie trać słów darmo,

Biją na larmo!

Za tą pobudką jak zagrzeją głowy,

Usłyszysz różne bohatyrów mowy:

Mnie nigdy straszna nie jest ordy zgraja,

Jam wziął Neczaja.

Jam Karaszmurze z Supenkazim gromił, Jam Kinigsmarka szkwadrony przełomił,

Od mej walecznej szable Dothoruki

Rozsiekan w sztuki.

Jam w Holzacyjej nieleniwym chodem 
Stanął, straszny gość pod Fryderyszodem,

Jam pierwszy w szturmie toruńskim na wały

Wpadał zuchwały.

Ej, stójcie, bracia! Czy chcecie mizernie

Poginąć wszyscy przy lubym falernie?

Czy wino lejąc, iże krew lejecie,

Rozumieć chcecie?

Inszy krwie męskiej, inszy kolor trunku,

Różnego kryształ z żelazem gatunku;

Języka dzieło słowami wotować,

$$
\text { Ręki - wojować. }
$$

Zaniechajcież już tej daremnej chluby,

Boć się i same śmieją $z$ was cekuby.

To mi bohatyr, co milcząc przy stole,

Chowa się w pole.

(Przy petnych zwycięstwo. Do Panów Biberonich Bellisarów, L I 6, s. 21-23)

Tutaj znów wykorzystano kontrast jako podstawowy środek obrazowania. Nadrzędne jest porównanie pola bitwy do suto zastawionego stołu — i analogicznie — walki do biesiady. Leksyka łącząca kręgi semantyczne bitwy (wojny) i uczty (jedzenia) wprowadza interesujący zabieg kontrastu poetyckiego (jak w strofie „Placem wojennym nam stól...”). Zestawienie obu kręgów semantycznych przebiega nawet na poziomie połączeń leksykalnych (wyrażeń, zwrotów): „obóz ze śkła”; „z mis beloardy, z pasztetów reduty” i inne. To dodatkowo przybliza pola znaczeniowe. Paradoksalnie w przywołanym tekście poeta charakteryzuje dwie biegunowo różne cechy Sarmaty: waleczność i sybarytyzm, pierwszą z nich chwaląc, drugą - ganiąc. Służyć mają temu liczne przeciwstawienia („Czy wino lejąc, iże krew lejecie, / Rozumieć chcecie? / Inszy krwie męskiej, inszy kolor trunku, / Różnego kryształ z żelazem gatunku”). Kontrast zatem służyć ma obnażeniu wad i słabości Sarmaty, jak również obudzeniu w nim (czy przypomnieniu) cech jednoznacznie pozytywnych.

Sarmata jako postać, „główny bohater" Sarmacji, bywa w poezji Kochowskiego szczegółowo opisany. Oto dwie sąsiadujące z sobą pieśni księgi I:

\section{Husarza-ć piszę, nie jak ma być w boju}

Kawaler, ale i cery i stroju

Takiego: naprzód powagi zażywać,

Sam jakby perfekt, inszych pociaszywać.

Ostro, ogromno ma sobie poczynać,

Okiem orzech gryźć, wąsem muchy ścinać;

Wąs ową fozą nową bałłabańską,

Jeśli chce brodę, niechaj ma katańską.

Animusz pański, niech zarywa bokiem 
Poważnym sobie postępując krokiem,

Patrząc na ludzi, jedno mruży oko,

Krząka i spluwa na wiatr gdzieś wysoko.

We łbie paragraf - prawie wrąb śmiertelny,

Przez gębę podłuż nożyk po szabelnéj

Jest parenthesis $z$ drugiej dana strony,

Ów od ordyńca, ten od cudnej żony.

Kontusz czy toga? Pod nią cudne rysie,

Na czele stawa, baranie, umkniej się!

Albo też soból, co z Moskwy tą furą

Przywiezion, dyszy mu pod brandebura.

Telej z turecka gęstą strefą złotą,

Pas w karmazynie sekiemską robotą,

Portki z purpury kęs mniejsze, niż one,

Co tam mają być w Sasiech zawieszone.

Andzar za pasem, denuszka złocona

Przy boku, wszytka turkusy sadzona;

Amelija mu wisi aż na brzuchu

$\mathrm{Na}$ złotym w ziarnka grochowe łańcuchu.

$\mathrm{Na}$ głowie szturmak soboli z zaponą,

Ten pod nożykiem wdział na bakier stroną;

Lub też zażyje czasem czaplej kity,

A w ręku nadziak trzyma złotolity.

Bot z turska wielki, co by sam spadł z nogi,

Przy nim albańskie przydłuższym ostrogi,

Albo też, kiedy nie ma jachać w drogę,

Baczmagi wdziewa sudanne na nogę.

Koń sekiel — wszytek w bród ufarbowany,

$\mathrm{Na}$ którym czoldar złotem hafowany,

Siodło rumelskie w jaszczur, złote rzędy,

Złotem koń odzian, złotem brząka wszędy.

Humor, strój i koń zalecenie daje

Usarzom. Którym tego trojga staje,

Nie tylko się z nich Bellonie w tej mierze

Każdy, leć samej zaleci Wenerze.

(Husarz od stryja synowcowi zaciagającemu się postany, L I 25, s. 48-51)

Nie to husarz, co groźny humor ma w pokoju,

Nie ten, co wąsem trząsa, kiedy przy napoju

Kandyskim posiedziawszy, puchary rychtuje,

Do marcypanowego Kartagu szturmuje, 
Z tabelatury stąpa, krok liczy leniwy,

Właśnie ni żółwia gonił pies, pokarmu chciwy;

Ale ten, który w polu przy Marsowej dumie

Ostro, groźno, ogromno postępować umie.

Wrodzonego humoru namniej nie nicuje,

Tak w boju, jak w pokoju jednakim się czuje,

Ze pstrym chamaleontem nic farby nie mieni, Jednakim zawsze w polnej Marsowej przestrzeni.

Co do twarzy ogromnej, do piwnego wąsa,

Którym często opiły w karczmie chłop potrząsa:

Starszy był, niż Bałłaban, Achilles on mężny

(Lada dziad brodę nosi, przecie niedołężny)

Bez brody był, dlatego uszedł w fraucymerze,

Ustąpił mu i Hektor dzielności w tej mierze.

Nie mierzą chłopa w korzec, często mały bije,

A wielki z piwnym wąsem nadstawuje szyje;

Często mały kurteczka dotrzymuje wilka,

Czemu by nie zdołało i złajników kilka.

Srąm husarza nie zdobi, nie byl srąmowaty

Aleksander, co podbić pragnął oba światy.

Z wojny z przeciętą gębą bardzom widział mało,

Raczej się im to w giełdzie lub w karczmie dostało.

Bardziej patrzy ordyniec bułatem swym karku,

A zaś w gębę najprędzej urwie na jarmarku.

Pas, nóż, bot, czapka, portki usarza nie zdobią,

Bez tego być nie moga i co pługiem robią.

$Z$ rynsztunku znać husarza, po koniu, po zbroi,

Czego się barziej Kozak niźli wąsów boi;

Koń dzielny, kirys mocny, siodło i z koncerzem

Ogromnym w boju czynią husarza rycerzem.

(Replika na to od synowca stryjowi, L I 26, s. 51-53)

Przeciwstawione sobie wizerunki husarza oparte są na kontraście deskrypcji. Pierwszy z tekstów, zachowując klasyczny porządek opisu (od góry do dołu), uwypukla atrybuty wyglądu, szczególnie akcentując elementy urody i stroju: oczy, wąsy, brodę, „andzar” (sztylet) czy damasceńską szablę („denuszka”). Atrybutom tym w drugim tekście przeciwstawione zostają (najczęściej na zasadzie ironicznego zaprzeczenia) elementy wyglądu właściwe prawdziwemu żołnierzowi („Z rynsztunku znać husarza, po koniu, po zbroi...”). Enumeracja jako najprostszy wykładnik formalny opisu służy w przytoczonych cytatach intensyfikacji wrażeń odbiorcy. Znaczne nagromadzenie atrybutów zwraca na nie uwagę, tym samym umacnia kontrast obu kontekstów opisowych. Liczne przeciwstawienia stanowią interesujący koncept wykraczający poza granice jednego utwo- 
ru. Przedstawione wizerunki: dandysa i próżniaka (Husarz...) oraz żołnierza i patrioty (Replika...) jednoznacznie wskazują też na konflikt pokoleń (patrz: informacja o nadawcy $i$ adresacie w tytułach utworów) - ale to młodsze pokolenie okazuje się bardziej odpowiedzialne.

Przeprowadzona obserwacja pozwala wysnuć wnioski na temat poezji Kochowskiego, pozostającej w kręgu oddziaływania nurtu sarmackiego polskiej literatury barokowej. Można wskazać cechy składające się na stereotyp polskiego Sarmaty - żołnierza i patrioty. Stanowią one dwie grupy, obejmujące właściwości pozytywne i negatywne, są to: przywiązanie do polskiej tradycji oraz wzorców antycznych, waleczność, odwaga, patriotyzm z jednej strony oraz megalomania, sybarytyzm, próżność, zawziętość — z drugiej. Autostereotyp Sarmaty wyłaniający się z poezji Kochowskiego poświęconej tematyce historycznej i społecznej (w pewnym sensie historiozoficznej) jest więc strukturą dynamiczną i wieloaspektową. Poeta, choć sam uznający się za obywatela Sarmacji, nie szczędzi słów krytyki i przedstawia własną wizję Sarmaty, wizję wielopłaszczyznową i przez to - wydaje się - prawdziwą.

Stylistycznym wykładnikiem charakterystyk jest przede wszystkim kontrast. Jezzykowo bywa on wyrażony poprzez zderzenie konwencji poetyckich (potoczność - artyzm - retoryczność), zbliżenie przeciwstawnych pól semantycznych czy różnego rodzaju zabiegi z kręgu szeroko rozumianej intertekstualności, jak odwołania do historii i kultury, w tym także starożytnej.

Poddana analizie poezja w pełni oddaje synkretyzm literatury polskiego baroku z całym spektrum zabiegów stylistycznych, konwencji i poetyk, pozwalając jednocześnie odtworzyć jeden z wzorców osobowych (stereotypów) tamtych czasów. I właśnie niejednoznaczność stylistyczna poezji barokowej, owe „kategorie rozmyte” - formy tej twórczości, które uczeni od dawna starają się uporządkować ${ }^{9}$, okazują się czymś niezwykle pomocnym w odtwarzaniu światów za słowami, a tym samym w przybliżaniu współczesnemu odbiorcy człowieka dawnych wieków.

\footnotetext{
${ }^{9}$ Zob. np.: T. Skubalanka, Glówne tendencje stylistyczne w polskiej poezji barokowej, w: Barok w polskiej kulturze, literaturze i jęzүku, red. M. Stępień, S. Urbańczyk, Warszawa-Kraków 1992, s. 189-198; A. Wilkoń, Kategorie stylistyczne w poezji barokowej, w: idem, Jezyk artystyczny. Studia i szkice, Katowice 1999, s. 131-144.
} 